\title{
Francisella noatunensis subsp. orientalis outbreak in Nile tilapia juveniles cultivated in net cages in the Araguari river basin, Brazil
}

\author{
Surto de Francisella noatunensis subsp. orientalis em tilapias do Nilo juvenis cultivadas em tanque- \\ redes na bacia do rio Araguari, Brasil
}

Surto de Francisella noatunensis subsp. orientalis en tilapias del Nilo juveniles cultivadas en estanques de red en la región la cuenca del río Araguari, Brasil

Received: 08/11/2021 | Reviewed: 08/18/2021 | Accept: 08/20/2021 | Published: 08/22/2021

\author{
Mariela Moura Carreon \\ ORCID: https://orcid.org/0000-0002-4981-4318 \\ Universidade Federal de Uberlândia, Brazil \\ E-mail: marielasmoura@yahoo.com.br \\ Pedro Henrique de Oliveira Viadanna \\ ORCID: https://orcid.org/0000-0001-8171-4053 \\ Fundação Presidente Antônio Carlos, Brazil \\ E-mail: pedroh1986@gmail.com \\ Líria Queiroz Luz Hirano \\ ORCID: https://orcid.org/0000-0002-9438-7538 \\ Universidade de Brasília, Brazil \\ E-mail: liriahirano@unb.br \\ Miguel Frederico Fernandez-Alarcon \\ ORCID: https://orcid.org/0000-0001-7206-2209 \\ Prevet Sanidade Aquícola, Brazil \\ E-mail: miguelffa@hotmail.com \\ Igor Paula de Castro \\ ORCID: https://orcid.org/0000-0003-0655-0399 \\ Universidade Federal de Uberlândia, Brazil \\ E-mail: igorpcastro@ufu.br \\ Danilo Guedes Junqueira Junior \\ ORCID: https://orcid.org/0000-0001-8171-4053 \\ Centro Universitário do Triângulo, Brazil \\ E-mail: dan_hp2002@yahoo.com.br \\ Higor Oliveira Silva \\ ORCID: https://orcid.org/0000-0001-9197-7383 \\ Faculdade Cidade de Coromandel, Brazil \\ E-mail: higorvet@yahoo.com.br \\ Frederico Augusto de Alcântara Costa \\ ORCID: https://orcid.org/0000-0001-8992-1786 \\ Universidade Federal de Uberlândia, Brazil \\ E-mail: frederico.costa@ufu.br \\ Anna Monteiro Correia Lima \\ ORCID: https://orcid.org/0000-0001-9567-3627 \\ Universidade Federal de Uberlândia, Brazil \\ E-mail: annalima@ufu.br
}

\begin{abstract}
The aims at identifying and describing the occurrence ofanatomopathological and histopathological changes in Nile tilapia juveniles, naturally infected with Francisella noatunensis subsp. orientalis (Fno). The Nile tilapias of this study were cultivated in net cages in the region of the Araguari River basin, Minas Gerais, Brazil, and due to a mortality rate ranging from 40 to $60 \%, 64$ fish samples were collected and sent for examination in the laboratory. At necropsy, granuloma-like nodules were observed in the spleen 59/64(92.2\%), kidney 24/64 (37.5\%), and liver 09/64 (14.1\%). Fno was detected in 98\% (49/50) of the samples by PCR. Upon analysis, astrong correlation was observed between external and internal lesions, since granulomatous lesions present in the spleen and kidney of the same animal simultaneously were also accompanied by skin ulcers, suggesting that the cutaneous lesion is related to the presence of Fno in tilapia and can be used as an indication for early diagnosis. Thus, the high prevalence of Fno observed in this research study allows characterizing an outbreak in the region. It is noteworthy that especially regarding the consumption of tilapia meat, although there are zoonotic species in the Francisella group, the zoonotic potential of Fno is not yet known and should be further studied.
\end{abstract}

Keywords: Granuloma; Cutaneous lesion; Oreochromis niloticus. 


\begin{abstract}
Resumo
Objetivou-se neste estudo identificar e descrever a ocorrência de alterações anatomopatológicas e histopatológicas em tilápias do nilo juvenis, naturalmente infectadas por Francisella noatunensis subsp. orientalis (Fno). As tilápias do Nilo deste estudo foram cultivadas em tanques-rede na região da bacia do rio Araguari, Minas Gerais, Brasil, cuja taxa de mortalidade variou de 40 a $60 \%$, das quais 64 amostras de peixes foram coletadas e enviadas para exame em laboratório. Na necropsia, foram observados nódulos semelhantes a granulomas no baço 59/64 (92,2\%), rim 24/64 (37,5\%) e fígado 09/64 (14,1\%). Fno foi detectado em 98\% (49/50) das amostras por PCR. Na análise dos resultados, observou-se forte correlação entre lesões externas e internas, uma vez que lesões granulomatosas presentes no baço e rim simultaneamente do mesmo animal, eram acompanhadas de úlceras cutâneas, sugerindo que a lesão cutânea está relacionada à presença de Fno nas tilápias, indicando assim, que este achado possa ser utilizado como ferramenta importante para o diagnóstico precoce da doença. Dessa forma, a alta prevalência de Fno observada nesta pesquisa permite caracterizar um surto na região. Ressalta-se que principalmente em relação ao consumo de carne de tilápia, embora existam espécies zoonóticas no grupo Francisella, o potencial zoonótico do Fno ainda não é conhecido e deve ser melhor estudado.
\end{abstract}

Palavras-chave: Granuloma; Lesão cutânea; Oreochromis niloticus.

\title{
Resumen
}

El objetivo de este estudio fue identificar y describir la ocurrencia de alteraciones anatomopatológicas e histopatológicas en tilapias juveniles del Nilo, naturalmente infectadas por Francisella noatunensis subsp. orientalis (Fno). Las tilapias del Nilo de este estudio fueron cultivadas en estanques de red en la región de la cuenca del río Araguari, Minas Gerais, Brasil, cuya tasa de mortandad varió entre 40 y 60\%, de las cuales 64 muestras de peces fueran recolectadas y enviadas a exámenes en laboratorio. En la necropsia, se observaron nódulos semejantes a granuloma en el bazo 59/64 (92,2\%), riñón 24/64 (37,5\%) e hígado 09/64 (14,1\%). Fno fue detectado en 98\% (49/50) de las muestras por PCR. En el análisis de los resultados, se observó fuerte correlación entre lesiones externas, una vez que lesiones granulomatosas presentes en el bazo y riñón, simultáneamente del mismo animal, se acompañaban de úlceras cutáneas, sugiriendo que la lesión cutánea está relacionada a la presencia de Fno en las tilapias, revelando que este hallazgo pueda ser utilizado como herramienta importante para el diagnóstico precoz de la enfermedad. Así siendo, la alta prevalencia de Fno observada en dicha investigación perite caracterizar un surto en la región. Se destaca que principalmente en relación al consumo de carne de tilapia, por más que existan especies zoonóticas en el grupo de Francisella, el potencial zoonótico del Fno todavía no es conocido y debe ser mejor estudiado.

Palabras clave: Granuloma; Lesión cutánea; Oreochromis niloticus.

\section{Introduction}

Nile tilapia (Oreochromis niloticus, Linnaeus, 1758) is a tropical cichlid that originated from the Nile River basin, in Africa (Trewavas, 1983). This species has great economic importance for aquaculture in Brazil and was the most produced fish in 2019, with over 480 tonnes (Valenti, Barros, Moraes-Valenti, Bueno, \& Cavalli, 2021). The use of net cages is very widespread activity in Brazilian aquaculture, because occupies existing water bodies and requires low implementation investment compared to earthen ponds (Andrade, 2020).

The growth and intensification of tilapia production in Brazil have created an environment that favors the occurrence of epizootic outbreaks of infectious diseases, resulting from the high stock density, increased stress, higher amplitude of environmental parameters, and various mismanagements (Tavares-Dias, 2009; Raghiante, Ferrasso, Rodrigues, Biondi, \& Martins, 2017). Additionally, it is understood that tilapia is susceptible to infection by several different bacteria (Soto, Bowles, Fernandez, \& Hawke, 2010; Baumgartner, \& Hawke, 2011; Costa, Leal, Leite, \& Figueiredo, 2014). Francisellosis is a disease caused by different species of the bacterial genus Francisella and, among them, Francisella noatunensis subsp. orientalis (Fno) is a Gram-negative and intracellular facultative pathogen that has been associated with massive deaths and outbreaks worldwide (Assis, Oliveira, Figueiredo, \& Leal, 2016). In Brazil, outbreaks of granulomatous disease in Nile tilapia fingerlings reared in floating cages have been reported since 2012 (Joshi, Almeida, Costa, Skaarud, Pádua Pereira, Knutsen \& Alvarez, 2021).

Fno affects tilapia and other important fresh and marine warm-water fish (Birkbeck, Feist, \& Verner-Jeffreys, 2011), and the disease is especially harmful to immunosuppressive fish, such as fingerlings and juveniles, normally when the water 
temperature is below $25^{\circ} \mathrm{C}$ (Qiang, Ningqiu, Xiaozhe, Qiandong, Ouqin, Lihui, \& Shuqin, 2015, Ortega, Mancera, Enriquez, Vargas, Martínez, \& Romero, 2016).

Francisellosis in fish is known to cause high morbidity and mortality rates and is associated with small white nodules present histologically as granulomas in multiple organs, especially the spleen, kidney, and liver (Birkbeck, Feist, \& VernerJeffreys, 2011; Colquhoun, \& Duodu, 2011, Fernandez-Alarcon, Santana, Viadanna, Manzini, Natori, Ishikawa, \& Tachibana, 2019). The diagnosis of infections by Fno is challenging because it is a fastidious bacterium to grow. However, histopathology together with the conventional PCR technique are the best tools to use due to high sensitivity and specificity and are becoming more popular and accessible in Brazil (Soto, Bowles, Fernandez, \& Hawke, 2010; Duodu, Larsson, Sjoédin, Soto, Forsman, \& Colquhoun, 2012; Assis, Oliveira, Figueiredo, Leal, 2016; Raghiante, Ferrasso, Rodrigues, Biondi, \& Martins, 2017).

Understanding the importance of fish health in Brazil is imperative and the main objective of this study is to describe and characterize the outbreak of Fno in Nile tilapia juveniles cultivated in net cages in the Araguari River Basin, Minas Gerais, thus contributing to the understanding of the disease while assisting the field diagnosis.

\section{Methodology}

The study was approved by the Ethics Committee on the Use of Animals (CEUA) from the Federal University of Uberlandia, protocol 079/17.

The form of exploration used was a case study, where an exploratory descriptive study of fish mortality was carried out, and if necessary, the characterization of the etiological agent (Pereira, Shitsuka, Parreira, \& Shitsuka, 2018).

The tilapias used in this study were harvested from four fish farms with mortality rates between 40-60\%, according to producers. All studied fish farms are located in the hydrographic basin of the Araguari River, Minas Gerais, Brazil (Figure 1).

Figure 1. Approximate location of A, B, C and D fish farms in the Araguari River Basin, in the state of Minas Gerais, Brazil.

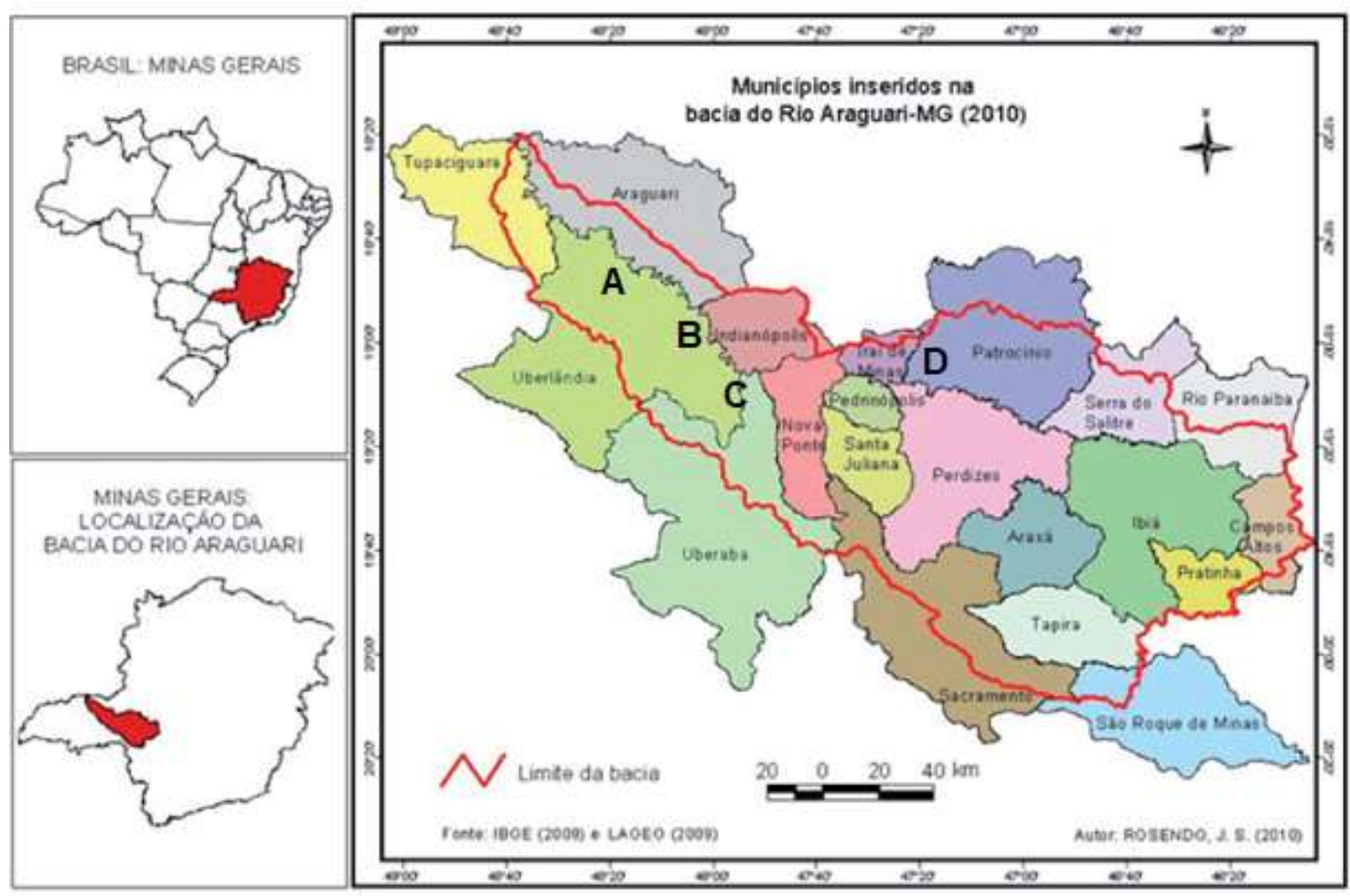

Source: Adapted from Rosendo and Rosa (2012). 
The tilapias were sampled in July 2017, when the average minimum and maximum temperatures were 14.5 and $24^{\circ} \mathrm{C}$, respectively (INMET, 2017). A total of 64 Nile tilapia juveniles weighing between 80 and 250 grams were collected from the net cages using a fishing net.

The sampled tilapia presented at least one of these clinical signs including hypoxia, apathy, lethargy, isolation, erratic swimming, pallor of the skin or gills, ulcers near the fins, and spots on the body.

After sampling, the tilapias were separated into groups of 5 placed in plastic bags, which contained water from the same net cage as the fish, and appropriately tied and labeled. The bags with the live tilapias were stored in polystyrene boxes containing ice and transported to the Laboratory of Infectious Diseases of the Federal University of Uberlândia (LADOC UFU).

The animals were euthanized following the Euthanasia Practice Guidelines of the Animal Experimentation Committee (CONCEA). Subsequently, the specimens were necropsied according to Noga (2010), an incision along the visceral cavity opened and exposed the internal organs. Upon careful visual examination, the macroscopic findings worthy of note were reported on spreadsheets.

After that, the 50 specimens with the most visible lesions were selected for molecular diagnosis. Spleen fragments were immersed in absolute alcohol, identified according to its pisciculture of origin (A1 to A13; B1 to B5; C1 to C24; D1 to D25), then sent for molecular identification by conventional PCR following the protocol of Hsieh, Tung, Tu, Chang, and Tsai (2006) in the Aquaculture Diagnostic and Health Laboratory (PREVET) in Jaboticabal, SP. An aliquot of $5 \mu$ l of the obtained PCR products were applied on agarose gel at 1.5\% fused in buffer TAE 1X (40mM Tris-acetate, 1mM EDTA; pH 8.0), and subjected to electrophoresis, following the recommendations of Sambrook, and Russell (2001). The PCR test was performed in triplicate to guarantee reliable results.

The necropsy and molecular identification results were entered into a Microsoft Excel® spreadsheet for descriptive analysis. The agreement between the test results was determined by the Kappa coefficient at 5\% significance using the Bioestat 5.4 software (Ayres, Ayres Júnior, Ayres, Santos, \& Ayres, 2007).

\section{Results}

Upon examination, the tilapia juveniles showed the following clinical signs: apathy, lethargy, isolation, pallor of the skin and/or gills, and skin ulcers mostly near the fins. The necropsy revealed multifocal to coalescent multiple white nodules in the parenchyma of the spleen, kidney, and liver and the results were agruppaded (Table 1).

Table 1. Relationship between the results of different diagnostic methods such as skin lesions, presence of nodules in the spleen and other organs, and PCR.

\begin{tabular}{|c|c|c|c|c|c|}
\hline \multirow[b]{2}{*}{ Fish farms } & \multirow[b]{2}{*}{$\begin{array}{l}\text { Number of tilapia } \\
\text { collected }\end{array}$} & \multirow[b]{2}{*}{ Skin Lesions } & \multirow{2}{*}{$\begin{array}{l}\text { White nodules } \\
\text { suggestive of granuloma } \\
\text { in the spleen }\end{array}$} & \multicolumn{2}{|c|}{ PCR } \\
\hline & & & & $\mathrm{N}^{\mathrm{o}}$ & Positives \\
\hline A & 13 & 4 & 13 & 12 & 11 \\
\hline $\mathrm{B}$ & 5 & 0 & 5 & 4 & 4 \\
\hline $\mathrm{C}$ & 24 & 10 & 21 & 19 & 19 \\
\hline $\mathrm{D}$ & 25 & 23 & 23 & 15 & 15 \\
\hline \multirow{2}{*}{ TOTAL } & 64 & 37 & 62 & 50 & 49 \\
\hline & $100 \%$ & $57.81 \%$ & $96.88 \%$ & $100 \%$ & $98 \%$ \\
\hline
\end{tabular}


The spleen was the most affected organ, with lesions observed in $92.2 \%$ of the samples, followed by the kidney $(37.5 \%)$ and liver $(14.1 \%)$. All tilapia juveniles with lesions in the kidney and/or liver also had nodules in the spleen. It was also noted that debilitated fish with visible white spleen nodules also had skin ulcers (Figure 2).

Figure 2. Macroscopic and microscopic lesions observed in Nile tilapia juveniles with mortality in fish farms located in the hydrographic basin of the Araguari River, Minas Gerais, Brazil.

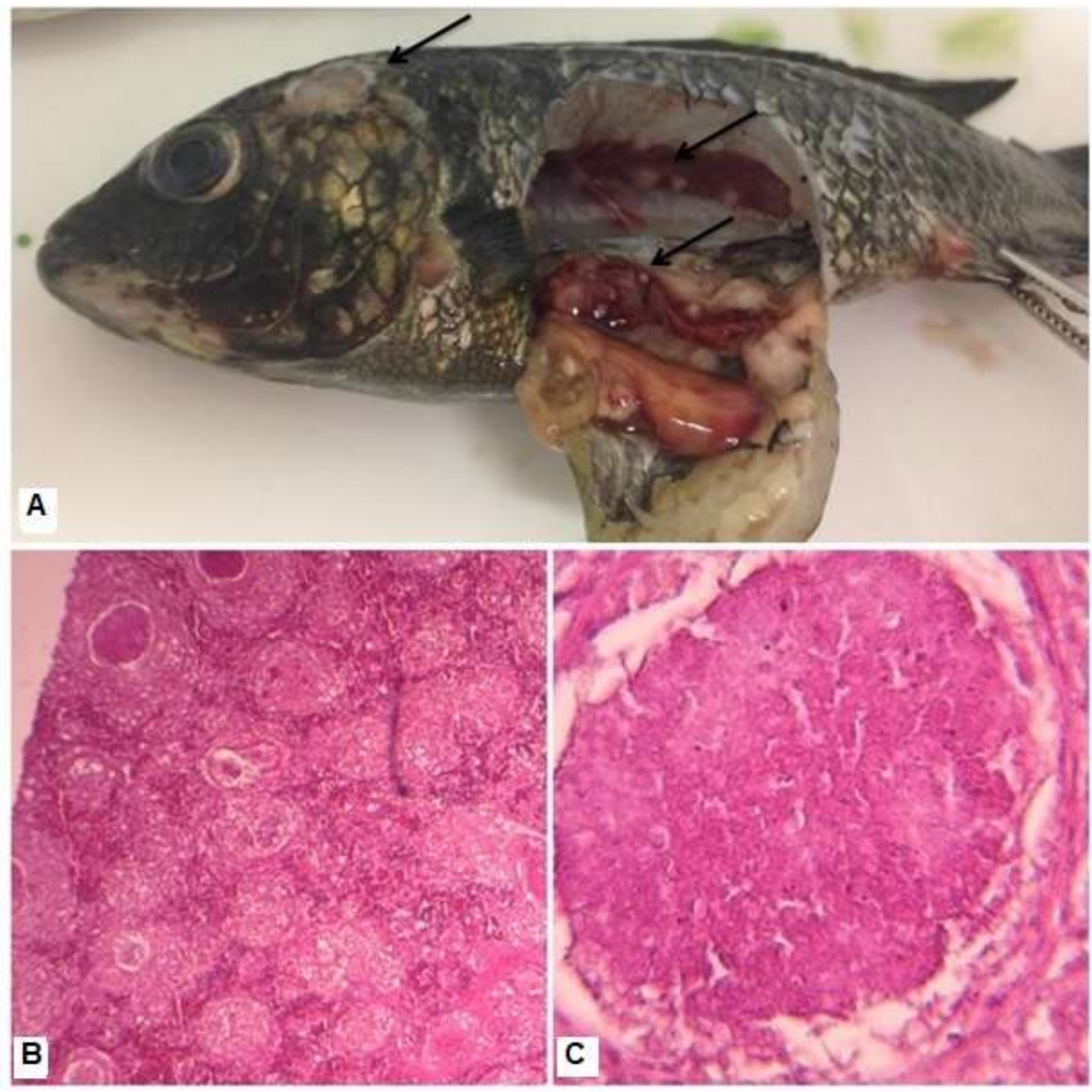

A: Tilapia with skin ulcer and white nodules in the spleen and kidney (black arrow). B: Photomicrograph of tilapia spleen, showing multiple granulomatous foci, characterizing marked granulomatous splenitis, (4x). Hematoxylin and eosin (HE). C: Photomicrograph of tilapia, Granuloma spleen (40x). (HE). Source: Authors.

As seen in Figure 2.A., the symptoms of patches and ulcers skin, it was especially easy to see. Furthermore, PCR detected Fno in $98 \%$ of the tilapia spleen fragments analyzed, except for only one of the examined fragments that appeared without lesions. The kappa test results were agruppaded in Table 2. 
Table 2. Association between the results obtained for skin lesion and spleen branch without nodules by PCR using Fischer's exact test.

\begin{tabular}{lccrr}
\hline & & \multicolumn{3}{c}{ Nodules } \\
& & & + & - \\
\hline & + & & 44 & 5 \\
PCR & - & & 1 & 0 \\
Kappa & & 0,88 & p value & 0,37 \\
\hline \multicolumn{3}{c}{ Skin ulcer } \\
& & & + & - \\
\hline & + & & 26 & 23 \\
PCR & - & & 1 & 0 \\
Kappa & & 0,52 & p value & 0,17 \\
\hline \multicolumn{3}{c}{ Source: Authors. }
\end{tabular}

Table 2 shows the kappa test results while indicating an almost perfect agreement between the presence of nodules and the PCR results (Table 2).

\section{Discussion}

Native from the Levante area in Africa, the Nile Tilapia is a tropical cichlid that can tolerate a wide range of environmental conditions (El-Sayed, 2006). However, the immune system and metabolism can be impaired by low water temperature (below $20^{\circ} \mathrm{C}$ ), making it more susceptible to pathogens that can thrive in lower water temperatures, like the Fno, an emerging pathogen whose pathogenesis remains relatively unknown (Soto, Bowles, Fernandez, \& Hawke, 2010; Leal, Tavares, \& Figueiredo, 2014; Jatobá, Klipp, \& Hoppe, 2016; Assis, Tavares, Pereira, Figueiredo, \& Leal, 2017; Pereira, Tavares, Carvalho, Rosa, Rezende, Leal, \& Figueiredo, 2019).

Raghiante (2016) conducted a study on Francisella spp. and reported a $4 \%$ prevalence in a random sample of 150 tilapia spleens from the Araguari River region. However, this work reveals a larger and wider prevalence of this disease in the same Basin, indicating a stronger and more widespread impact than previously reported. Therefore, sanitary measures are required to improve fish health security for tilapia farmers in this region. Although the pathogenicity mechanisms of Fno are little understood, it is acknowledged that these bacteria present an expressive infection rate and remarkable ability to persist in the environment (Soto, Brown, Gardenfors, Yount, Revan, Francis, \& Camus, 2014). Also, because the Fno transmission between fish is proven to be through water (Fernandez-Alarcon, Santana, Viadanna, Manzini, Natori, Ishikawa, \& Tachibana, 2019), it would be wise not to raise juvenile fish in fishnets, especially during cold seasons.

Recent studies indicated that the clinical outcome of francisellosis in tilapia has a clear relationship with water temperature since tilapia mortality rate has been observed to increase by $30 \%$ for a temperature drop from 28 to $22^{\circ} \mathrm{C}$ (Lewis, \& Soto, 2019; Pereira, Tavares, Carvalho, Rosa, Rezende, Leal, \& Figueiredo, 2019). It is also known that the expression levels of virulence of the FNO genes change when the bacterium is exposed to temperatures below $25^{\circ} \mathrm{C}$ and oxidative stress. Therefore, it is possible to conclude that the microorganism survives/multiplies and adapts, changing the expression level of genes related to several functions, including stress tolerance and oxidative stress regulators, thus improving both Fno fitness and growth rates in the new water conditions (Ferullo, \& Lovett, 2008; Dalebroux, \& Swanson, 2012).

The high rate of multiple white nodules found in tilapia spleen, kidney, and liver in this study originate from the intracellular characteristic of Fno, which triggers the humoral and cellular defense, especially via Th1 (Crane, Griffin, Wehrly, $\&$ Bosio, 2013), leading to the formation of a granuloma. It is also involved in the elimination of molecular patterns associated 
with pathogens (PAMPs) through processes of innate immunity. Multifocal whitish nodules in the spleen, kidney, and other organs were also described in previous reports on Franciselose (Leal, Tavares, \& Figueiredo, 2014; Sebastião, Pilarski, Kearney, \& Soto, 2017).

The fact that the fish are immunosuppressed and with a lower metabolism, made the fish more prone to infection/infestation, generating a moderate mortality rate in the assessed farms, and explaining some of the clinical signs, as apathy and anorexia (Zago, Franceschini, Garcia, Schalch, Gozi, \& Silva, 2014).

In this study, we observed simultaneous clinical symptoms in the spleen and kidney, and also skin spots and ulcers, especially near the fins, witch observed in Figure 2.A. This correlation has not been reported in works previously conducted in the study region (Leal, Tavares, \& Figueiredo, 2014; Jatobá, Klipp, \& Hoppe, 2016; Assis, Oliveira, Figueiredo, \& Leal, 2016; Raghiante, 2016; Sebastião, Pilarski, Kearney, \& Soto, 2017; Rodrigues, Francisco, David, Silva, Falcone-Dias, \& Araújo Júnior, 2018).

Previous works have demonstrated that the impact of temperature in Brazilian fish farms during the cold seasons, may or may not be associated with coinfection with another pathogen (Soto, Abrams, \& Revan, 2012; Leal, Tavares, \& Figueiredo, 2014; Assis, Tavares, Pereira, Figueiredo, \& Leal, 2017). Lesions on the skin are particularly challenging to pin to a unique etiology, as these can be associated with various pathogens, such as Trichodina spp., Ichthyophthirius multifiliis, Cichlidogyrus halli, Cichlidogyrus thurstonae, Cichlidogyrus sp., Scutogyrus longicornis, Gyrodactylus sp., Epistylis sp., Piscinoodinium pillulare (Zago, Franceschini, Garcia, Schalch, Gozi, \& Silva, 2014). However, Trichodina spp. lesions occur distributed in the regions near the fins, but do not appear in the spleen (Valladão, Alves, \& Pilarski, 2016). Cichlidogyrus sp. causes damage to the fish gills, which turn pale (Yusni, \& Rambe, 2019). The macroscopical lesion of Piscinoodinium pillulare causes a moderate increase in the quantity of mucus with brown to green lumps on the body surface, partial loss of the fins and gills with multifocal hemorrhagic areas on the skin (Ferreira Junior, Leonardo, Azevedo, Rodrigues, Nascimento, Macêdo, \& Pedroso, 2018), characteristics that were not observed in this study.

The high number of lesions in the spleen fragments of tilapia from lots with high mortality in this study is most likely due to its hematopoietic and lymphoid function (Neyrão, 2017). One of the functions of the spleen is to produce the melanomacrophage centers (MMCs), which are macrophages aggregations within lipofuscin, hemosiderin, ceroid and melanin (Balamurugan, Deivasigamani, Kumaran, Sakthivel, Rajsekar, \& Priyadharsini, 2012). MMCs are responsible for antigen presentation, Fno will enter the fish dendritic cell and inside the phagosome, it will migrate to fish MMCs, causing the peculiar fast granulomatous lesion in the spleen, kidney, and liver.

The confirmation of the Fno presence in the tilapia tank nets assessed by PCR in this study highlights the importance of effectively performing the sanitary inspection of fish in pisciculture. In scenarios limiting the use of direct diagnosis by PCR, necropsy provides data complementary to clinical and epidemiological analysis.

The data from the kappa test indicate that macroscopic analysis with the identification of nodules is an important tool in clinical practice since it showed an index of 0.88 considered an almost perfect condition. As seen in Figure 2.A., the symptoms of patches and ulcers skin, it was especially easy to see.

Based on the outbreaks in Brazil, the tilapia farmers apparently have limited knowledge of the prevailing health problems and still rarely implement effective biosecurity practices to prevent the introduction of economically important infectious agents (Leal, Tavares, \& Figueiredo, 2014; Delphino, Leal, Gardner, Assis, Roriz, Ferreira, \& Gonçalves, 2019). 


\section{Conclusion}

In conclusion, Fno presents a wide range and high prevalence in the Araguari River, and the observed skin lesions and associated mortality indicate the necessity of preventive actions to lower the mortality rate, such as good management techniques, fish inspection for detecting lesions, necropsy, and PCR for detecting Fno.

\section{Acknowledgments}

This study was financed in part by the Coordenação de Aperfeiçoamento de Pessoal de Nível Superior - Brazil (CAPES) - Finance Code 001.

\section{Ethics approval statement}

The study was approved by the Ethics Committee on the Use of Animals (CEUA) from the Federal University of Uberlandia, protocol 079/17.

\section{References}

Andrade, A. S. (2020). Aquicultura brasileira: a visão do Ministério da Agricultura, Pecuária e Abastecimento a partir do sistema de registro geral da pesca e aquicultura. Research, Society and Development, 9(10), e2759108398-e2759108398. http://dx.doi.org/10.33448/rsd-v9i10.8398

Assis, G. B. N., Oliveira, T. F., Figueiredo, H. C., \& Leal, C. A. G. (2016). Sensitivity and specificity of real-time PCR and bacteriological culture for francisellosis in farm-raised Nile tilapia (Oreochromis niloticus L). Journal of fish diseases, 40(6), 785-795. https://doi.org/10.1111/jfd.12559

Assis, G. B. N., Tavares, G. C., Pereira, F. L., Figueiredo, H. C. P., \& Leal, C. A. G. (2017). Natural coinfection by Streptococcus agalactiae and Francisella noatunensis subsp. orientalis in farmed Nile tilapia (Oreochromis niloticus L.). Journal of fish diseases, 40(1), 51-63. https://doi.org/10.1111/jfd.12493

Ayres, M., Ayres Júnior, M., Ayres, D. L., Santos, A. A. S., \& Ayres, L. L. (2007). BioEstat 5.4: aplicações estatísticas nas áreas das ciências biológicas e médicas. 5. ed. Belém, PA: Publicações Avulsas do Mamirauá. https://www.researchgate.net/profile/Alex-De-Assis-Dos-Santos2/publication/263608962_BIOESTAT_-_aplicacoes_estatisticas_nas_areas_das_Ciencias_Bio-Medicas/links/02e7e53b598e69ebfe000000/BIOESTATaplicacoes-estatisticas-nas-areas-das-Ciencias-Bio-Medicas.pdf

Balamurugan, S., Deivasigamani, B., Kumaran, S., Sakthivel, M., Rajsekar, T., \& Priyadharsini, P. (2012). Melanomacrophage centers aggregation in P lineatus spleen as bioindicator of environmental change Asian Pacific. Journal of Tropical Disease, 2(S2), S635-S638. https://doi.org/10.1016/S2222$1808(12) 60235-7$

Baumgartner, W. A., Hawke, J. (2011). Bacterial diseases cause granulomas in fish: varied staining methods identify pathogens. Global Aquaculture, 14(4), 34-36.

Birkbeck, T. H., Feist, S. W., \& Verner-Jeffreys, D. W. (2011). Francisella infections in fish and shellfish. J Fish Dis, 34(3), 173-187. https://doi.org/10.1111/j.1365-2761.2010.01226.x

Colquhoun, D. J., \& Duodu, S. (2011). Francisella infections in farmed and wild aquatic organisms. Veterinary Research, 42(1), 47. https://doi.org/10.1186/1297-9716-42-47

Costa, F. A. A., Leal, C. A. G., Leite, R. C., \& Figueiredo, H. C. P. (2014). Genotyping of Streptococcus dysgalactiae strains isolated from Nile tilapia, Oreochromis niloticus (L). Journal of fish diseases, 37(5), 463-469. https://doi.org/10.1111/jfd.12125

Crane, D. D., Griffin, A. J., Wehrly, T. D., \& Bosio, C. M. (2013). B1a cells enhance susceptibility to infection with virulent Francisella tularensis via modulation of NK/NKT cell responses. The Journal of Immunology, 190(6), 2756-2766. https://doi.org/10.4049/jimmunol.1202697

Dalebroux, Z. D., \& Swanson, M. S. (2012). ppGpp: magic beyond RNA polymerase. Nature Reviews Microbiology, 10(3), 203-212. https://doi.org/10.1038/nrmicro2720

Delphino, M. K. V. C., Leal, C. A .G., Gardner, I. A., Assis, G. B. N., Roriz, G. D., Ferreira, F., \& Gonçalves, V. S. P. Seasonal dynamics of bacterial pathogens of Nile tilapia farmed in a Brazilian reservoir. Aquaculture, 498, 100-108. https://doi.org/10.1016/j.aquaculture.2018.08.023

Duodu, S., Larsson, P., Sjoèdin, A., Soto, E., Forsman, M., \& Colquhoun, D. J. (2012). Real-time PCR assays targeting unique DNA sequences of fishpathogenic Francisella noatunensis subspecies noatunensis and orientalis. Diseases of Aquatic Organisms, 101(3), 225-234. https://doi.org/10.3354/dao02514

El-Sayed, A. F. M. (2006). Tilapia Culture., Wallingford, UK: CABI International Publishing. https://doi.org/10.1079/9780851990149.0000

Fernandez-Alarcon, M. F, Santana, A. M., Viadanna, P. H. O., Manzini, B. Natori, M. M., Ishikawa, C. M. \& Tachibana L. (2019). Nile tilapia (Oreochromis niloticus) challenged infection by Francisella noatunensis subsp. orientalis via an intragastric route protocol, Aquaculture, 510, 380-385. https://doi.org/10.1016/j.aquaculture.2019.06.007 
Ferullo, D. J., \& Lovett, S. T. (2008). The stringent response and cell cycle arrest in Escherichia coli. PLoS genetics, 4(12), e1000300. https://doi.org/10.1371/journal.pgen.1000300

Hsieh, C. Y., Tung, M. C., Tu, C., Chang, C. D., \& Tsai, S. S. (2006). Enzootics of visceral granulomas associated with Francisella-like organism infection in tilapia (Oreochromis spp). Aquaculture, 254, 129-138. https://doi.org/10.1016/j.aquaculture.2006.03.044

Instituto Nacional de Meteorologia (INMET). (2017). Estação de Uberlândia Temperatura no período de 01 de Julho de 2017 a 31 de Julho de 2017. http://wwwinmetgovbr/portal/indexphp?r=home/page\&page=rede_estacoes_auto_graf

Jatobá, A., Klipp, S. P., \& Hoppe, R. (2016). Primeiro relato de Francisella noatunensis subespécie orientalis no sul do Brasil-relato de caso. Acta Veterinaria Brasilica, 10(2), 172-176. DOI: https://doi.org/10.21708/avb.2016.10.2.5512

Joshi, R., Almeida, D. B., Costa, A. R., Skaarud, A., Pádua Pereira, U., Knutsen, T. M., ... \& Alvarez, A. T. (2021). Genomic selection for resistance to Francisellosis in commercial Nile tilapia population: genetic and genomic parameters, correlation with growth rate and predictive ability. Aquaculture, 537, 736515. https://doi.org/10.1016/j.aquaculture.2021.736515

Ferreira Junior, J. A., Leonardo, A. S., Azevedo, J. P. M. V. B., Rodrigues, F. R., Nascimento, K. A., Macêdo, J. T. S. A., \& Pedroso, P. M. O. (2018). Outbreak of Infection by Piscinoodinium pillulare and Trichodina spp. in Tambaquis (Colossoma macropomu), Pirapitingas (Piaractus brachypomus) and Tilapias (Oreochromis niloticus) in the Federal District, Brazil. Acta Scientiae Veterinariae, 46, 293. https://doi.org/10.22456/1679-9216.86827

Leal, C. A., Tavares, G. C., \& Figueiredo, H. C. (2014). Outbreaks and genetic diversity of Francisella noatunensis subsp orientalis isolated from farm-raised Nile tilapia (Oreochromis niloticus) in Brazil. Genetics and Molecular Research, 13(3), 5704-5712. https://doi.org/10.4238/2014.July.25.26

Lewis, J., \& Soto, E. (2019). Gene expression of putative type VI secretion system (T6SS) genes in the emergent fish pathogen Francisella noatunensis subsp. orientalis in different physiochemical conditions. BMC microbiology, 19(1), 1-9. https://doi.org/10.1186/s12866-019-1389-7

Linnaeus, C. (1758). Systema Naturae per regna tria naturae, secundum classes, ordines, genera, species, cum characteribus, differentiis, synonymis, locis. (10th revis. ed., vol. 1). Laurentius Salvius: Holmiae.

Neyrão, I. M. (2017). Mediação de respostas imunes e do sistema de defesa antioxidante pelo cortisol em pacu (Piaractus mesopotamicus). (Dissertação de Mestrado), Universidade Estadual Paulista, Jaboticabal. https://repositorio.unesp.br/bitstream/handle/11449/150261/neyrao_im_ me_jabo_int.pdf?sequence=6\&isAllowed=y

Noga, E. J. (2010). Fish disease: diagnosis and treatment. Hoboken, Nova Jersey: Blackwell Publishing.

Ortega, C., Mancera, G., Enriquez, R., Vargas, A. Martínez, S., \& Romero, A. (2016). First identification of Francisella noatunensis subsp orientalis causing mortality in Mexican tilapia Oreochromis spp. Diseases of Aquatic Organisms, 120(3), 205-215. https://doi.org/10.3354/dao02999

Pereira, A. S., Shitsuka, D. M., Parreira, F. J., \& Shitsuka, R. (2018). Metodologia da pesquisa científica.

Pereira, F. L., Tavares, G. C., Carvalho, A. F., Rosa, J. C. C., Rezende, C. P., Leal, C. A. G., \& Figueiredo, H. C. P. (2019). Effects of temperature changes in the transcriptional profile of the emerging fish pathogen Francisella noatunensis subsp. orientalis. Microbial pathogenesis, $133,103548$. https://doi.org/10.1016/j.micpath.2019.103548

Qiang, L., Ningqiu. L., Xiaozhe. F., Qiandong. H., Ouqin, C., Lihui L., \& Shuqin, W. (2015). An outbreak or granulomatous inflammation associated with Francisella noatunensis subsp orientalis in farmed tilapia (Oreochromis niloticus x $O$ aureus) in China Chinese. Chinese Journal of Oceanology and Limnology, 34(3), 460-466. https://doi.org/10.1007/s00343-016-4311-2

Raghiante, F. (2016). Francisella noatunensis orientalis em tilápias (Oreochromis niloticus) cultivadas em tanques-rede na bacia hidrográfica do rio Araguari - Minas Gerais. (Tese de Doutorado), Universidade Estadual Paulista Júlio de Mesquita Filho, Botucatu, SP.

Raghiante, F., Ferrasso, M. M., Rodrigues, M. V., Biondi, G. F., \& Martins, O. A. (2017). Francisella spp. em tilápias no Brasil: uma revisão. Revista Brasileira de Higiene e Sanidade Animal, 11(1), 119-130. Recuperado de http://www.higieneanimal.ufc.br/seer/index.php/higieneanimal/article/view/385

Rodrigues, M. V., Francisco, C. J., David, G. S., Silva, R. J., Falcone-Dias, M. F., Araújo Júnior, J. P. (2018). Monitoring of Francisella noatunensis subsp. orientalis in farmed Nile tilapia (Oreochromis niloticus) in Brazil. Aquaculture Internationa, 26(1), 127-138. http://dx.doi.org/10.1007/s10499-017-0204-4

Rosendo, J. S., \& Rosa, R. (2012). Comparação do estoque de C estimado em pastagem e vegetação nativa de cerrado. Sociedade \& Natureza, 24(2), 59-379. DOI: http://dx.doi.org/10.1590/S1982-45132012000200014

Sambrook, J. F., \& Russell, D. W. (2001). Molecular Cloning: A Laboratory Manual, (3rd ed.), Cold Spring Harbor Laboratory Press.

Sebastião, F. A., Pilarski, F., Kearney, M. T., \& Soto, E. (2017). Molecular detection of Francisella noatunensis subsp orientalis in cultured Nile tilapia (Oreochromis niloticus L) in three Brazilian states. Journal of fish diseases, 40(11), 1-5. https://doi.org/10.1111/jfd.12636

Soto, E., Bowles, K., Fernandez, D., \& Hawke, J. P. (2010). Development of a real-time PCR assay for identification and quantification of the fish pathogen Francisella noatunensis subsp orientalis. Dis Aquat Organ, 89(3), 199-207. https://doi.org/10.3354/dao02204

Soto, E., Abrams, S. B., \& Revan, F. (2012). Effects of temperature and salt concentration on Francisella noatunensis subsp. orientalis infections in Nile tilapia Oreochromis niloticus. Diseases of aquatic organisms, 101(3), 217-223. https://doi.org/10.3354/dao02533.

Soto, E., Brown, N., Gardenfors, Z. O., Yount, S., Revan, F., Francis, S., \& Camus, A. (2014). Effect of size and temperature at vaccination on immunization and protection conferred by a live attenuated Francisella noatunensis immersion vaccine in red hybrid tilápia. Fish \& Shellfish Immunology, 41(2), 593-599. https://doi.org/10.1016/j.fsi.2014.10.009

Tavares-Dias, M. (2009). Manejo e sanidade de peixes em cultivo. Macapá, AP: Embrapa Amapá. https://www.infoteca.cnptia.embrapa.br/handle/doc/353099 
Research, Society and Development, v. 10, n. 11, e40101119332, 2021

(CC BY 4.0) | ISSN 2525-3409 | DOI: http://dx.doi.org/10.33448/rsd-v10i11.19332

Trewavas, E. (1983). Tilapiine fishes of the genera Sarotherodon, Oreochromis and Danakilia. London, UK: Bulletin of the British Museum (Natural History). 1983.

Valladão, G. M. R., Alves, L. O., \& Pilarski, F. (2016). Trichodiniasis in Nile tilapia hatcheries: diagnosis, parasite: host-stage relationship and treatment. Aquaculture, 451, 444-450. https://doi.org/10.1016/j.aquaculture.2015.09.030

Valenti, W. C., Barros, H. P., Moraes-Valenti, P., Bueno, G. W., \& Cavalli, R. O. (2021). Aquaculture in Brazil: past, present and future. Aquaculture Reports, 19, 100611. https://doi.org/10.1016/j.aqrep.2021.100611

Yusni, E., \& Rambe, N. (2019). Identification of ectoparasites in Fry Tilapia (Oreochromis Niloticus) in Aquaculture Pond. IOP Conference Series: Earth and Environmental Science, 260(1), 012110). https://doi.org/10.1088/1755-1315/260/1/012110

Zago, A. C., Franceschini, L., Garcia, F., Schalch, S. H. C., Gozi, K. S., \& Silva, R. J. (2014). Ectoparasites of Nile tilapia (Oreochromis niloticus) in cage farming in a hydroelectric reservoir in Brazil. Revista Brasileira de Parasitologia Veterinária, 23(2), 171-178. https://doi.org/10.1590/S1984-29612014041 